\title{
Effect of humidity on egg hatchability and reproductive biology of the bamboo borer (Dinoderus minutus Fabricius)
}

\author{
Ahmad R Norhisham ${ }^{1}$, Faizah Abood ${ }^{1 *}$, Muhamad Rita ${ }^{2}$ and Khalid Rehman Hakeem ${ }^{3 *}$
}

\begin{abstract}
Wood products are highly exposed to infestation by powder post beetles. Dinoderus minutus (bamboo borer) is a wood boring beetle that seriously damage dried bamboo and finished bamboo products. Management of $D$. minutus using pesticides showed negative effects on environment despite being very costly. By understanding influence of natural climatic conditions on their reproductive behaviour, could help us to develop a cost effective and environmental friendly strategy to cope up with this problem. In the present study, reproductive parameters and egg development of the bamboo borer were determined at $20 \%, 40 \%, 56 \%, 75 \%$ and $85 \%$ r.h. levels at constant temperature of $30^{\circ} \pm 2^{\circ} \mathrm{C}$ with $8 \mathrm{~L}-16 \mathrm{D}$ photoregime. From the results, eclosion to first instar larva was recorded at all relative humidities tested. The lowest shortest percentage of hatchability was recorded at 20\% and $85 \%$ relative humidity with a mean incubation period of $4.63 \pm 0.25$ and $10.43 \pm 0.32$ days, respectively. It was noted that pre-ovipositional period decreased from $14.20 \pm 0.49$ to $7.20 \pm 0.31$ days as relative humidity increased from $20 \%$ to $75 \%$ and slightly increased to $8.00 \pm 0.37$ days at $85 \%$ relative humidity. We conclude that female beetles may have a particular hygropreference in oviposition as total egg production increased with increasing relative humidity.
\end{abstract}

Keywords: Bostrychidae, Bamboo borer, Dinoderus minutus, Egg hatchability, Powderpost beetle, Reproductive capacity

\section{Introduction}

Plants are always under the influence of biotic as well as abiotic stressful conditions (Anjum et al. 2010; Hakeem et al. 2012). Plant-insect interactions are quite common in nature and sometimes very useful for both species, however, when insects showed negative interactions, resulting to cause direct damages to the plants or their products, they are termed as pests. Pests are known to attack the economically important plants and their products at both pre-harvest as well as post-harvest stages and responsible for huge economic losses (Agboka et al. 2010).To cope up with this problem, normally pesticides are used. However, besides being very costly, the indiscriminate use of these pesticides has now created serious health as well as

\footnotetext{
*Correspondence: faizah@putra.upm.edu.my; kur.hakeem@gmail.com 'Department of Forest Management, Faculty of Forestry, Universiti Putra Malaysia (UPM), 43400, Serdang, Malaysia

${ }^{3}$ Faculty of Forestry, Universiti Putra Malaysia, 43400 UPM, Serdang, Selangor, Malaysia

Full list of author information is available at the end of the article
}

environmental problems (Madhun and Freed 1990; Pimentel 2005; Devi 2007). Repeated application of pesticides leads to loss of biodiversity (Bengtsson et al. 2005). The latest trend is to understand the nature of reproductive biology of these pests and their dependence on several environmental conditions (Garcia and Morrell 2009).

Various climatic conditions are responsible for the normal reproduction, production of eggs as well as egg hatchability. Relative humidity can affect the physiology and thus the development, longevity and oviposition of many insects. At low relative humidities, development may be retarded, for example in many pests of stored products; at high relative humidities or in saturated air (100\% RH), insects or their eggs may drown or be infected more readily by pathogens (Gullan and Cranston, 2005). Different exposure of relative humidity on stored product pest, Tribolium castaneum, T. confusum (Coleoptera: Tenebrionidae) and Oryzaephilus surinamensis (Coleoptera: Cucujidae) showed increased insect mortality as relative humidity decreased 
(Jay et al. 1971). Low relative humidity can prevent embryo development and egg hatching due to loss of lubrication and cuticular softness in insect (Guarneri et al. 2002). High relative humidity contributes to population increase in stored product pest, as shown in Callosobruchus maculatus under laboratory conditions (Ouedraogoa et al. 1996). Female Callosobruchus maculatus showed higher fecundity and longer adult lifespan at high humidity. High humidity support reproductive capacity in insects as percentage of water is correlated with the amount of fat (including eggs in females), which consists of anhydrous molecules, and with the amount of cuticle, which has a lower water content than other tissues. Environmental temperature and humidity affects the developmental phase and transpiration through insect body surface (Chapman 1975; Guarneri et al. 2002). Insects must keep body water content within certain limits which is influenced by the degree of the insect cuticle permeability (Willmer, 1982; Raghu et al. 2004). Insect survival is influenced by its ability to tolerate fluctuations in body water influence by humidity (Romoser and Stoffolano, 1998).

The present study was concentrated to understand the effect of relative humidity on egg hatchability and reproductive capacity of bamboo borer (Dinoderus minutus). This study would help us to develop cost effective and environmental friendly strategies to control insect pests without any health hazards.

\section{Materials and methods Insect Culture}

Adult $D$. minutus were collected from infested bamboo culms in Bamboo Incubation Center and Handicraft in Simpang Pertang, Negeri Sembilan, Malaysia ( $2^{\circ} 57^{\prime} 25.61^{\prime \prime} \mathrm{N}$ $102^{\circ} 18^{\prime} 12.69^{\prime \prime E}$ ). Most bamboo culms infested by $D$. minutus belongs to the species Gigantochloa scortechinii, which is an important species of bamboo in Malaysia. Infested bamboo culms were kept in a plastic container with dimension of $30 \mathrm{~cm} \times 20 \mathrm{~cm} \times 25 \mathrm{~cm}$ kept in insect rearing room at $75 \%$ r.h. and $25 \pm 3^{\circ} \mathrm{C}$ with $8 \mathrm{~L}-16 \mathrm{D}$ photoregime. Newly emerged beetles were collected and introduced into a new culture jar with cassava block using standards techniques of culture described by Abood et al. (2010).

\section{Control of Relative humidity}

Different salt solutions and distilled water were used to control the relative humidity to which eggs and adult beetles were exposed. As indicated by Winston and Bates (1960), Roca and Lazzari (1994) and Dambach and Goehlen (1999), acid or inorganic (non-volatile) salt solutions were adequate for this purpose, as their water vapour pressure remained constant for long periods. The liquids used to establish the relative humidities were distilled water, saturated solutions of Potassium acetae $\left(\mathrm{CH}_{3} \mathrm{CO}_{2} \mathrm{~K}\right)$, Sodium iodide (NaI), Sodium bromide ( $\mathrm{NaBr}$ ), Sodium chloride
$(\mathrm{NaCl})$ and Potassium chloride $(\mathrm{KCl})$. The relative humidity was obtained by filling solutions at the bottom of desiccators and monitored using a digital thermohygrometer. Throughout the study, investigation on reproductive parameters and egg hatchability were carried out in Petri dishes kept in desiccators corresponding to each relative humidity and hermetically closed. The desiccators were put into an incubator with controlled temperature of $30 \pm 2^{\circ} \mathrm{C}$.

\section{Reproductive capacity}

Newly emerged beetles less than 7 days old were used to determine the effect of different relative humidities $(20 \%$, $40 \%, 56 \%, 75 \%$ and $85 \%$ r.h.) on reproductive parameters at constant temperature of $30^{\circ} \pm 2^{\circ} \mathrm{C}$ with $8 \mathrm{~L}-16 \mathrm{D}$ photoregime. Ten pairs of adult beetles were exposed at each relative humidity tested. Each pair of adults were selected and separately introduced into Petri dishes lined with cassava pellet and filter paper. Observation on egg production was then started after 24 hours of setup. Cassava pellets were removed and broken up daily to assess number of eggs laid. The cassava pellet was replaced each time after inspection on egg production. Data collection on adult longevity and fecundity were collected until complete mortality.

\section{Egg hatchability}

The effect of relative humidity on egg hatchability and incubation period was inspected under different relative humidity levels $(20 \%, 40 \%, 56 \%, 75 \%$ and $85 \%$ r.h.) at constant temperature of $30^{\circ} \pm 2^{\circ} \mathrm{C}$ with $8 \mathrm{~L}-16 \mathrm{D}$ photoregime. Newly laid eggs of $D$. minutus were obtained from an established $D$. minutus culture on cassava. A total of 50 eggs were placed equidistant into Petri dishes lined with black filter paper for each relative humidity tested. Each Petri dish was kept in desiccators corresponding to each relative humidity and hermetically closed. The desiccators were put into an incubator with controlled temperature of $30 \pm 2^{\circ} \mathrm{C}$. Petri dishes were kept under these conditions and observation on egg eclosion and incubation period were observed daily under stereomicroscope and compared. During observation, eggs were removed as required with respect to age in days with a fine brush. Each egg was mounted on a concave microscope slide with a cover slip. This method was carried out to minimize the effect of relative humidity during the non-test conditions.

\section{Statistical analysis}

Statistical analysis software (SAS version 9.2) was used for the analysis on egg hatching, reproductive capacity and adult longevity at different relative humidities. One Way Analysis of Variance (ANOVA) and Fisher's least significant difference (LSD) were used to test the effect of relative humidity on reproductive parameter and incubation period. 


\section{Results}

\section{Effect of relative humidity on egg hatchability}

The results presented in Table 1 shows a very high significant effect $(\mathrm{F}=242.30, \mathrm{DF}=4,45 ; \mathrm{p}<0.0001)$ of relative humidity on egg hatchability in $D$. minutus. There is no significant difference between incubation period at $40 \%$, $56 \%$ and $75 \%$ relative humidity $(\mathrm{p} \geq 0.05 ; \mathrm{CV}=16.63)$. The lowest and highest relative humidity caused a significant decrease in egg hatchability when compared with the intermediate relative humidity levels $(\mathrm{p} \geq 0.05$; $C V=16.63)$.

Highest eclosion to first instar larva was recorded at $75 \%$ relative humidity with $86 \%$ eclosion to success and a mean incubation period of $5.44 \pm 0.14$ days. Lowest relative humidity of $20 \%$ showed only $8 \%$ eclosion to success with a mean incubation period of $4.63 \pm 0.25$. Percentage of successful eclosion and incubation period increased with increasing relative humidity to $75 \%$. However for $85 \%$ relative humidity, the percentage of successful eclosion decreased to $46 \%$. This shows that egg development was affected by extremes in humidity (Plate 1). Longest incubation period was recorded at $85 \%$ relative humidity with a mean of $10.43 \pm 0.32$ days.

\section{Effect of relative humidity on reproductive capacity}

Boring activity on cassava pellet was recorded within 24 hours of exposure under each relative humidity. Results in Table 2 show highly significant relative humidity effect on both $D$. minutus reproductive capacity $(\mathrm{F}=388.91$, $\mathrm{DF}=4,45 ; \mathrm{p}<0.0001)$ and adult lifespan $(\mathrm{F}=464.70, \mathrm{DF}=4$, 45; $\mathrm{p}<0.0001)$. However, there is no significant difference in pre-ovipositional period between $56 \%$ and $75 \%$ relative humidity levels $(\mathrm{p} \geq 0.05 ; \mathrm{CV} ; 13.14)$. Female $D$. minutus showed shorter pre-ovipositional period with increasing relative humidity until $75 \%$. Ovipositional period ( $\mathrm{p} \geq 0.05$; $\mathrm{CV}=8.67)$ and mean number of eggs laid $(\mathrm{p} \geq 0.05$; $\mathrm{CV}=13.14$ ) showed no significant difference between $75 \%$ and $85 \%$ relative humidity levels. Shortest ovipositional period was recorded at $20 \%$ relative humidity with a mean of $3.8 \pm 0.64$ days while the longest ovipositional period was recorded at $85 \%$ relative humidity with a mean of $56.50 \pm 1.21$. Mean number of eggs laid increased from $3.20 \pm 0.31$ to $56.50 \pm 1.21$ from $20 \%$ to $85 \%$ relative

Table 1 Influence of relative humidity on egg eclosion

\begin{tabular}{ccc}
\hline Relative & \multicolumn{2}{c}{ Egg development } \\
\cline { 2 - 3 } humidity & Incubation period (day) & Hatchability \\
\hline $20 \%$ & $4.63 \pm 0.25 \mathrm{c}$ & $8 \%$ \\
$40 \%$ & $5.79 \pm 0.13 \mathrm{~b}$ & $66 \%$ \\
$56 \%$ & $5.49 \pm 0.18 \mathrm{~b}$ & $74 \%$ \\
$75 \%$ & $5.44 \pm 0.14 \mathrm{~b}$ & $86 \%$ \\
$85 \%$ & $10.43 \pm 0.32 \mathrm{a}$ & $48 \%$ \\
\hline
\end{tabular}

Means followed by the same letter in the same column are not significantly different ( $p \geq 0.05$, Fisher's least significant difference) $\mathrm{N}=50$. humidity, thus indicating a preference for higher relative humidity conditions. Similar increment was recorded on mean ovipositional period which showed an increase from $3.8 \pm 0.64$ to $54.80 \pm 0.94$ days. The pre-ovipositional period decreased with increasing relative humidity levels from $20 \%$ to $75 \%$. However, between $75 \%$ to $85 \%$ relative humidity, there was a significant increase in pre-ovipositional period. Adult lifespan for both sexes increase with increasing relative humidity. Female D. minutus had longer lifespan compared to male beetles under all relative humidities tested. There was no significant difference between adult lifespan for male ( $p>0.05 ; C V=7.26)$ and female ( $>0.05 ; C V=5.19)$ between $85 \%$ and $75 \%$ and $75 \%$ and $56 \%$ relative humidity, respectively. Earliest mortality for adult beetle was recorded at $20 \%$ relative humidity for male and for female beetle on day 16 and 18, respectively. Longest lifespan for male beetle was recorded at 67 day at $75 \%$ relative humidity while longest lifespan for female beetle was 74 days at $85 \%$ relative humidity.

Fecundity curves for $D$. minutus under different relative humidity are shown in Figure 1 . Fecundity curve for $40 \%, 56 \%$ and $75 \%$ show normal distribution with few fluctuations throughout the oviposition period. The lowest and highest relative humidity resulted in different fecundity curve pattern compared with the intermediate relative humidity. Peak fertility period was encountered earlier at $75 \%$ relative humidity on day 24 with a mean of 1.04 followed by day 27 at $56 \%$ and $85 \%$ relative humidity with a mean of 0.85 and 1.40 , respectively. Peak fertility period at lower relative humidity occurred at a mean of 0.80 on day 27 at $40 \%$ relative humidity while at $20 \%$ relative humidity fecundity curve obtained did not present peak fertility period as reproductive parameters recorded under this condition was very low.

\section{Discussion}

In order to establish a sustainable pest management, it is essential to know the physiology as well as reproductive capacity of pests viz-a-viz their relations with various natural climatic conditions. Thus present study was undertaken to investigate the effect of humidity on egg hatchability and reproductive biology of the bamboo borer (Dinoderus minutus Fabricus).

In our study, we found that egg mortality was highest at $20 \%$ and $85 \%$ relative humidity levels in Dinoderus minutus. Dehydration occurred at low relative humidity due to loss of moisture in the egg, which leads to contraction and shrinking of both the chorion and the embryo. For eggs, which survived the low relative humidity levels up to the prelarval stage, the eggs did hatch but due to dehydration and loss of lubrication and cuticular softness, the prelarva could not be released successfully from the chorion (Figure 2). This effect on eggs caused by loss of water has been reported by Woods and 
Table 2 Effect of relative humidity on reproductive capacity

\begin{tabular}{cccccc}
\hline $\begin{array}{l}\text { Relative } \\
\text { humidity }\end{array}$ & \multicolumn{4}{c}{ Reproductive parameter } \\
\cline { 2 - 7 } & $\begin{array}{c}\text { Preovipositional period } \\
\text { (day) }\end{array}$ & $\begin{array}{c}\text { Ovipositional period } \\
\text { (day) }\end{array}$ & $\begin{array}{c}\text { Mean no. of eggs laid per } \\
\text { female }\end{array}$ & $\begin{array}{c}\text { Female Lifespan } \\
\text { (day) }\end{array}$ & $\begin{array}{c}\text { Male Lifespan } \\
\text { (day) }\end{array}$ \\
\hline $20 \%$ & $14.20 \pm 0.49 \mathrm{a}$ & $3.80 \pm 0.64 \mathrm{~d}$ & $3.20 \pm 0.31 \mathrm{~d}$ & $22.30 \pm 0.79 \mathrm{c}$ & $20.00 \pm 0.62 \mathrm{c}$ \\
$40 \%$ & $11.80 \pm 0.44 \mathrm{~b}$ & $37.20 \pm 1.34 \mathrm{c}$ & $28.90 \pm 1.01 \mathrm{c}$ & $56.90 \pm 1.20 \mathrm{~b}$ & $49.70 \pm 1.15 \mathrm{~b}$ \\
$56 \%$ & $9.60 \pm 0.38 \mathrm{c}$ & $51.80 \pm 0.49 \mathrm{~b}$ & $43.00 \pm 1.65 \mathrm{~b}$ & $68.80 \pm 0.68 \mathrm{a}$ & $61.50 \pm 1.29 \mathrm{a}$ \\
$75 \%$ & $7.20 \pm 0.31 \mathrm{C}$ & $54.40 \pm 1.33 \mathrm{a}$ & $66.40 \pm 1.21 \mathrm{a}$ & $70.10 \pm 0.70 \mathrm{a}$ & $60.50 \pm 1.19 \mathrm{a}$ \\
$85 \%$ & $8.00 \pm 0.37 \mathrm{~d}$ & $56.50 \pm 1.21 \mathrm{a}$ & $68.90 \pm 3.07 \mathrm{a}$ & $69.40 \pm 1.52 \mathrm{a}$ & $59.80 \pm 1.13 \mathrm{a}$ \\
\hline
\end{tabular}

Means followed by the same letter in the same column are not significantly different ( $\mathrm{p} \geq 0.05$, Fisher's least significant difference) $\mathrm{N}=20$.

Singer (2001) on Lepidoptera. Excessive moisture has shown to be detrimental to insect's survival (Prakash, 2008). At $85 \%$ relative humidity, the incubation period prolonged and $52 \%$ of the total number of egg exposed failed to hatch due to excessive moisture, which caused egg mortality. Previously, such negative effect of extreme relative humidity conditions on egg development and hatchability has been reported on the stink bug, Nezara viridula (Linnaeus) (Hirose et al. 2006) and the haematophagous bug Triatoma brasiliensis (Guarneri et al. 2002). The extension of embryonic development duration at lower humidities (and constant temperature) is a result of the depression of egg metabolism due to water loss (Zrubek and Woods 2006); low humidities induce in some insect eggs (collembolans, grasshoppers) a dormancy, which may last several months (Wigglesworth 1972). Similar Study by Alex (1983) on the humidity effect on Atherigona soccata showed that low humidity increases water loss on the chorion, and resistance to desiccation depends on the ability of the egg to retain water through physical and physiological processes.
From the observations in this study, most eclosion to first instar larva of $D$. minutus took place in the morning. During this period, relative humidity reaches its daily maximum. This may be a way to prevent desiccation of emerging larvae. This phenomenan of insect egg hatching at dawn has also been reported previously in different heteropteran species (Lazzari, 1991; Guarneri et al. 2002) and the tiger moth, Atteve sciodoxa Meyrick (Bajwa, unpubl. data 2009).

Female D. minutus showed heterogeneous ovipositional pattern with most eggs being laid at higher relative humidities and the mean number of eggs laid increased from $3.20 \pm 0.31$ to $56.50 \pm 1.21$ at $20 \%$ to $85 \%$ relative humidities, respectively. The effect of relative humidity on oviposition indicates that females may have a particular hygropreference in oviposition as total egg produced and ovipositional period increased with increasing relative humidity. However, observation on egg hatchability showed that high relative humidity of $85 \%$ resulted with low egg hatchability (Table 1). These results might explain how female D. minutus was capable to reproduce at high relative
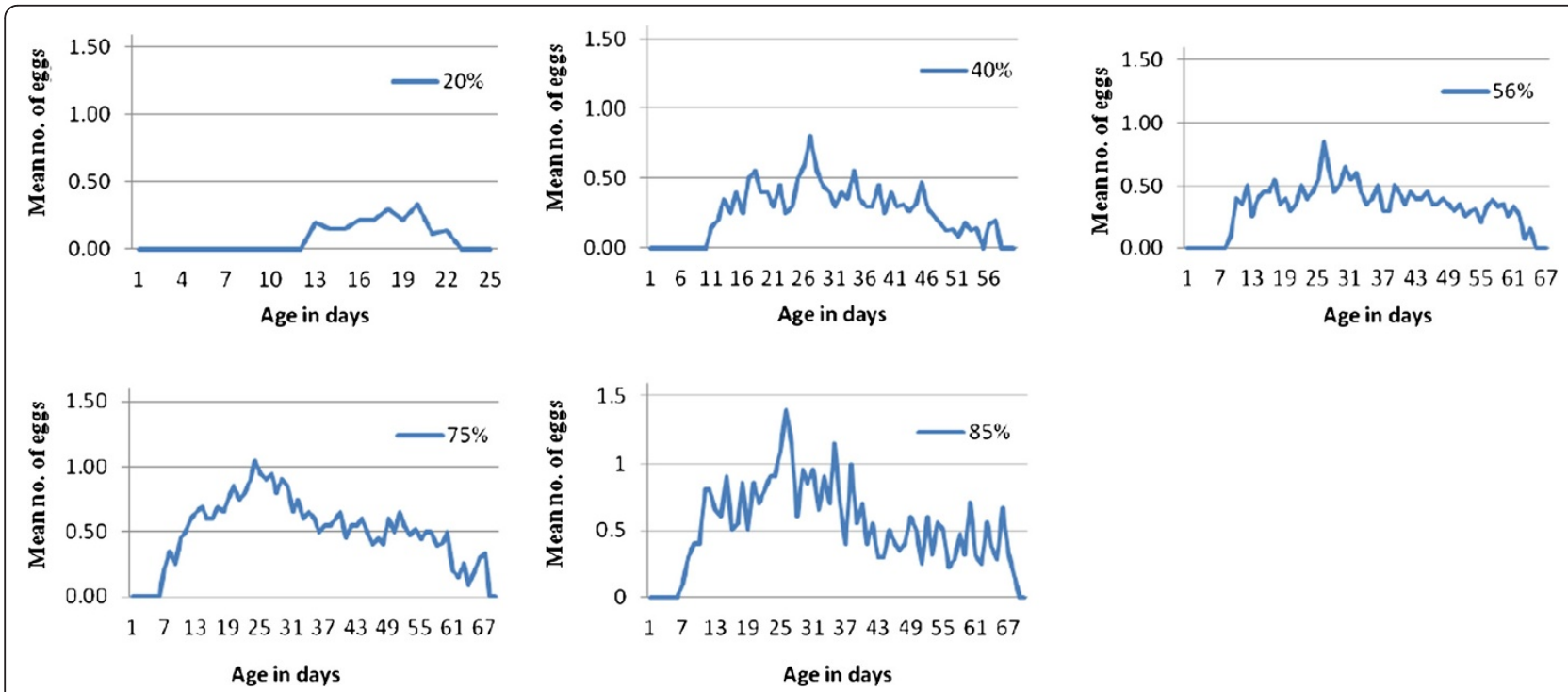

Figure 1 Age-specific fecundity curves of $D$. minutus at different relative humidities. 


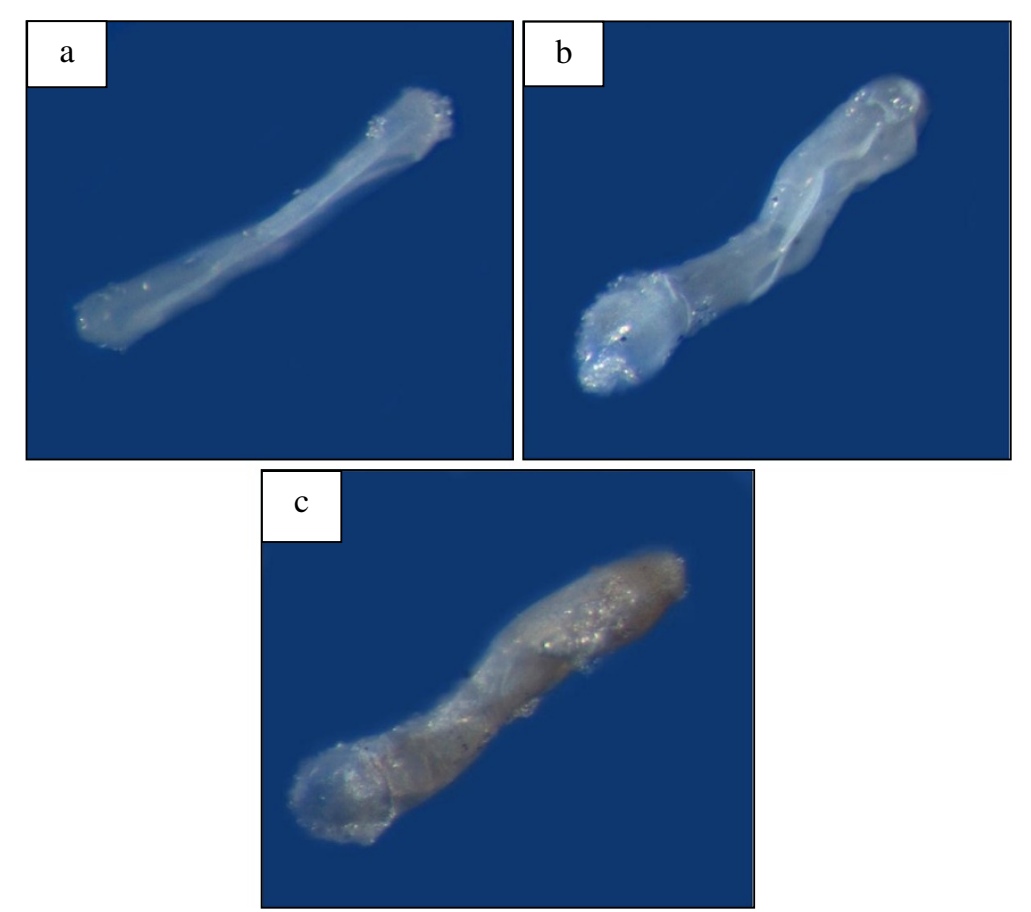

Figure 2 Effects of different relative humidities on D. minutus egg (x40): a. Newly laid egg; b. shrinkage of egg at $20 \%$ relative humidity; c. cuticular softening due to absorption of moisture at $56 \%$ relative humidity and $\mathrm{d}$. swelling of prelarva within chorion at $85 \%$ relative humidity.

humidity at early infestation in bamboo storage. As relative humidity decreased during the processing of bamboo culm, egg hatchability increases causing a pest outbreak. Romoser and Stoffolano (1998) stated that low humidity adversely affect the rate of insect oviposition in general. A study by Saha et al. (2011) showed that total progeny of Xylocoris flavipes decreased at high relative humidity of 90\%. David and Ananthakrishnan (2004) suggested that the fecundity of an insect is greatest at 70\% relative humidity, as seen in Locusta spp. Andrewartha and Birch (1954) reported that newly emerged adult migratory locusts did not produce eggs below $40 \%$ relative humidity. D. minutus response towards relative humidity was found to be similar to the rice weevil, Sitophylus oryzae, an important pest in stored product. Fecundity of S. oryzae increased with increasing moisture content of wheat from $34 \%$ to $70 \%$ relative humidity (David and Ananthakrishnan, 2004).

\section{Conclusion}

The effect of relative humidity on D. minutus egg hatchability showed high mortality at $20 \%$ and $85 \%$ relative humidity levels compared to that between $40 \%$ to $75 \%$. Lowest egg hatchability was recorded at $20 \%$ and $85 \%$ relative humidity levels. D. minutus egg suffers from loss of moisture that leads to shrinkage of both the embryo and chorion which prevents larval release. High relative humidity at $85 \%$ resulted in egg mortality due to excessive moisture. Reproductive capacity and incubation period of $D$. minutus increased with increasing relative humidity. Mean number of eggs laid increased from $3.20 \pm 0.31$ to $56.50 \pm 1.21$ from $20 \%$ to $85 \%$ relative humidity. Female beetle preferred to lay eggs in higher relative humidity as the number of eggs increased with increasing relative humidity. Pre-ovipositional decreased with increasing relative humidity. However at $85 \%$ relative humidity, preovipositional period increased slightly compared to $75 \%$ relative humidity. Ovipositional period prolonged as relative humidity increased. Adult female showed higher fecundity characteristics with increasing relative humidity. Mean ovipositional period increased from $3.8 \pm 0.64$ to $54.80 \pm 0.94$ days with increasing relative humidity. The present study would help scientist to work out the strategy/s about the biological control of pests without causing any damage to health, environment as well as economy.

Competing interests

The authors declare that they have no competing interests.

Authors' contributions

NAR and FA develop the research framework and facilitate laboratory experiment. MR and $\mathrm{KRH}$ helped and advised preparations of the manuscript. All authors have read and approved the final version of the manuscript for publication. 


\section{Acknowledgements}

The authors wish to acknowledge the Ministry of Higher Education, Malaysia, for the FRGS grant and Universiti Putra Malaysia for financial assistance and facilities.

\section{Author details}

${ }^{1}$ Department of Forest Management, Faculty of Forestry, Universiti Putra Malaysia (UPM), 43400, Serdang, Malaysia. ${ }^{2}$ Department of Plant Protection, Faculty of Agriculture, Universiti Putra Malaysia, (UPM), 43400, Serdang, Malaysia. ${ }^{3}$ Faculty of Forestry, Universiti Putra Malaysia, 43400 UPM, Serdang, Selangor, Malaysia.

Received: 29 October 2012 Accepted: 8 January 2013 Published: 11 January 2013

\section{References}

Abood F, Norhisham AR, Shahman M, Andy A (2010) Sexual identification of bamboo borer, Dinoderus minutus Fabricius (Coleoptera:Bostrychidae). The Malay For 73(1):1-6

Agboka K, Schulthess F, Tamo M, Hell K, Vidal S (2010) The importance of Mussidia nigrivenella Ragonot (Lepidoptera: Pyralidae) as a post-harvest pest in different storage structures in Benin. J of Stor Prod Res 46:81-86

Alex GLD (1983) Humidity effects on Atherigona soccata: Egg development and hatch. Ent Exp Di Appl 33:269-275

Andrewartha HG, Birch LC (1954) The Distribution and Abundance of Animals. The University of Chicago Press, Chicago

Anjum NA, Umar S, Chan M-T (eds) (2010) Ascorbate-Glutathione Pathway and Stress Tolerance in Plants. Springer (Science + Business Media B.V.), Dordrecht, The Netherlands. doi:10.1007/978-90-481-9404-9

Bengtsson J, AhnstrÖM J, Weibull AC (2005) The effects of organic agriculture on biodiversity and abundance: a meta-analysis. J of Appl Eco 42(2):261-269

Chapman RF (1998) The insects: structure and function, 4th edn. University Press, Cambridge

Dambach M, Goehlen B (1999) Aggregation density and longevity correlate with humidity in first-instar nymphs of the cockroach (Blatella germanica $L$., Dictyoptera). J of Ins Phys 45:423-429

David BV, Ananthakrishnan TN (2004) General and applied entomology. McGrawHill, New Delhi

Devi IP (2007) Pesticide use in the rice bowl of Kerala: Health costs and policy options. SANDEE, Nepal

Garcia CM, Morrell JJ (2009) Development of the Powderpost Beetle (Coleoptera: Bostrychidae) at Constant Temperatures. Environ Entomol 38(2):478-483

Guarneri AA, Lazzari C, Diotaiuti L, Lorenzo MG (2002) The effect of relative humidity on the behaviour and development of Triatoma brasiliensis. Phys Entomol 27:142-147

Gullan PJ, Cranston PS (2005) The Insects: An Outline of Entomology 3rd edition. Blackwell, London

Hakeem KR, Chandna R, Parvaiz A, Muhammad I, Munir O (2012) OMICS. A J of Integra Biol 16(11):621-663

Hirose E, Panizzi AR, Cattelan AJ (2006) Effect of relative humidity on emergence and on dispersal and regrouping of first instar Nezara viridula (L.) (Hemiptera: Pentatomidae). Neotrop Entomol 35(6):57-61

Jay EG, Arbogast RT, Pearman GC Jr (1971) Relative humidity: Its importance in the control of stored-product insects with modified atmospheric gas concentrations. J of Stor Prod Res 4:325-329

Lazzari CR (1991) Circadian rhythm of egg hatching in Triotoma infestans (Hemiptera: Reduviidae). J Med Entomol 28:740-741

Madhun YA, Freed VH (1990) Impact of pesticides on the environment. In: Pesticides in the soil environment: processes, impacts, and modeling. SSSA Inc, Madison

Ouedraogoa PA, Soua S, Sanona A, Mongea JP, Huignarda J, Trana B, Credland PF (1996) Influence of temperature and humidity on populations of Callosobruchus maculatus (Coleoptera: Bruchidae) and its parasitoid Dinarmus basalis (Pteromalidae) in two climatic zones of Burkina Faso. Bull Entomol Res 86(6):695-702

Pimentel D (2005) Environmental and economic costs of the application of pesticides primarily in the United States. Environ, Develop and Sustain 7 (2):229-252

Prakash M (2008) Encyclopaedia of Entomology. In: Insect Ecology. Discovery Pub, Delhi
Raghu S, Drew RAl, Clarke AR (2004) Influence of host plant structure and microclimate on the abundance and behaviour of a tephritid fly. J Ins Behav 17:179-190

Roca M, Lazzari CR (1994) Effects of the relative humidity on the haematophagous bug Triatoma infestans, Hygropreference and eclosion success. J of Ins Phys 10:901-907

Romoser WS, Stoffolano JG Jr (1998) The science of entomology, 4th edn. WCB McGraw-Hill, Boston

Saha SR, Islam W, Parween S (2011) Influence of Humidity and Tribolium Beetle Food Source On The Life History Characteristics of Predator, Xylocoris flavipes (Hemiptera: Anthocoridae). Trop Agr Research and Extension 15:1

Wigglesworth VB (1972) The principles of insect physiology, 7th edn. Chapman and Hall, London

Willmer PG (1982) Microclimate and the environmental physiology of insects. Ad Insect Physiol 16:1-57

Winston PW, Bates DH (1960) Saturated salt solutions for the control of humidity in biological research. Ecology 41:232-237

Woods HA, Singer MS (2001) Contrasting responses to desiccation and starvation by eggs and neonates of two Lepidoptera. Phys and Biochem Zoo 74:594-606

Zrubek B, Woods HA (2006) Insect eggs exert rapid control over an oxygen-water trade-off. Proc R Soc B 273:831-834

doi:10.1186/2193-1801-2-9

Cite this article as: Norhisham et al:: Effect of humidity on egg hatchability and reproductive biology of the bamboo borer (Dinoderus minutus Fabricius). SpringerPlus 2013 2:9.

\section{Submit your manuscript to a SpringerOpen ${ }^{\circ}$ journal and benefit from:}

- Convenient online submission

- Rigorous peer review

- Immediate publication on acceptance

- Open access: articles freely available online

- High visibility within the field

- Retaining the copyright to your article

Submit your next manuscript at springeropen.com 